\title{
Two Mutations in $\beta$-Tubulin 2 Gene Associated with Thiophanate-Methyl Resistance in Colletotrichum cereale Isolates from Creeping Bentgrass in Mississippi and Alabama
}

\author{
Joseph R. Young and Maria Tomaso-Peterson, Department of Entomology and Plant Pathology, Mississippi State \\ University, Mississippi State 39762; and Karla de la Cerda and Francis P. Wong, Department of Plant Pathology, \\ University of California, Riverside 92521
}

\begin{abstract}
Young, J. R., Tomaso-Peterson, M., de la Cerda, K. A., and Wong, F. P. 2010. Two mutations in $\beta$-tubulin 2 gene associated with thiophanate-methyl resistance in Colletotrichum cereale isolates from creeping bentgrass in Mississippi and Alabama. Plant Dis. 94:207-212.

Turfgrass anthracnose, caused by Colletotrichum cereale ( $\equiv$ C. graminicola), has become a common disease of creeping bentgrass putting greens during the summer in Mississippi and Alabama over the last 15 years. Thiophanate-methyl is a single-site mode-of-action fungicide applied to control C. cereale. In vitro bioassays were performed to evaluate the sensitivity of 103 isolates to thiophanate-methyl concentrations ranging from 0.039 to $10 \mu \mathrm{g} / \mathrm{ml}$. Eighty-three isolates were collected from creeping bentgrass in Mississippi and Alabama that had been exposed to thiophanate-methyl. An additional 20 isolates were included from nonexposed turfgrasses. Radial colony growth in amended media was relative to nonamended media for all in vitro bioassays. With thiophanate-methyl at $10 \mu \mathrm{g} / \mathrm{ml}$, relative growth of exposed isolates ranged from 77.5 to $130.7 \%$ with a mean of $99.3 \%$ compared with nonexposed, baseline isolates that ranged from 0.0 to $48.7 \%$ with a mean of $20.4 \%$. A representative sample of thiophanate-methylexposed and nonexposed isolates was used to determine the mechanism of resistance by comparing amino acid sequences of the $\beta$-tubulin 2 protein. All of the thiophanate-methyl-exposed isolates that were sequenced had a point mutation resulting in substitutions from glutamic acid to alanine at position 198 or from phenylalanine to tyrosine at position 200 of the $\beta$-tubulin 2 protein. These amino acid substitutions in $C$. cereale isolates from Mississippi and Alabama appear to confer resistance to thiophanate-methyl and differ from those reported previously for this pathogen.
\end{abstract}

Turfgrass anthracnose, incited by Colletotrichum cereale Manns ( $\equiv$ C. graminicola (Ces.) G.W. Wilson) (10), is a destructive disease of creeping bentgrass (Agrostis stolonifera L.) and annual bluegrass (Poa annua L.). The disease has been well documented on annual bluegrass golf course putting greens or fairways throughout the United States $(2,13,15,33,34)$; however, there is limited information available describing anthracnose on creeping bentgrass in the southern United States. C. cereale infects annual bluegrass year round, causing symptoms of foliar blight or basal rot when conducive environmental conditions occur. Regionally, the pathogen causes foliar blight on creeping bentgrass predominately in the summer

Corresponding author: M. Tomaso-Peterson E-mail:mariat@pss.msstate.edu

Current address of K. de la Cerda: Environmental Biology, University of Guelph, Ontario, N1G 2W1 Canada.

Approved for publication as Journal Article No. J11510 of the Mississippi Agriculture and Forestry Experiment Station, Mississippi State University.

Accepted for publication 5 October 2009.

doi:10.1094/PDIS-94-2-0207

(C) 2010 The American Phytopathological Society during periods of heat stress (29). The symptoms of anthracnose on creeping bentgrass putting green turf in Mississippi and Alabama include large, irregularly shaped thin areas appearing chlorotic to bronze (37).

Golf course superintendents in Mississippi and Alabama that manage creeping bentgrass putting greens initiate a preventive fungicide program in April to control anthracnose. Fungicides are applied on a biweekly basis through September or October, depending upon the environmental conditions. As a general means of disease prevention, single-site mode-of-action fungicides are applied alone or tank-mixed with multi-site mode-of-action fungicides such as chlorothalonil and mancozeb. Benzimidazoles, strobilurins, dicarboximides, and demethylation inhibitors are groups of single-site mode-of-action fungicides that are labeled for anthracnose control. However, repetitive applications of single-site mode-of-action fungicides to putting greens have resulted in increased selection pressure for fungicide resistance, as has been widely documented for several turf pathogens $(2,4,16,32,33)$.

Benzimidazole fungicides have been applied to highly managed golf turf in the southeastern United States for over 30 years but anthracnose severity on creeping bentgrass putting greens appears to have been increasing over the last 15 years. Cultural practices such as lower mowing heights, decreased nitrogen fertility, and reduced watering practices may have contributed to increased anthracnose incidence and severity on creeping bentgrass putting greens (8) but reduced fungicide efficacy may also be contributory.

The benzimidazole fungicides inhibit microtubule production by binding to the heterodimeric subunits of the tubulin molecule (26). Benzimidazole-resistant isolates of many fungi have been identified from a variety of crops. These isolates were determined to be resistant due to missense point mutations in DNA that result in amino acid exchanges in the $\beta$ tubulin 2 protein $(5,7,12,14,17,18,21-$ $23,26,28,35)$. According to a Fungicide Resistance Action Committee publication (1), there are four amino acid substitutions in the $\beta$-tubulin 2 protein that can predispose fungi to develop resistance to benzimidazole chemistries following excessive, repeated applications to a single population. At amino acid position 198, alanine (Ala), glycine (Gly), or lysine (Lys) is exchanged for glutamic acid (Glu); or, at amino acid position 200, tyrosine (Tyr) is exchanged for phenylalanine (Phe). Fungal isolates expressing one of these substitutions will fail to respond to benzimidazole fungicides due to a decreased binding affinity to the specific site within the gene leading to decreased disease control.

Detweiler et al. (13) reported that $C$. cereale isolates collected from annual bluegrass in Michigan as early as 1989 were resistant to benzimidazoles using in vitro and in vivo bioassays. C. cereale isolates collected from annual bluegrass in California have also been determined to be resistant to benzimidazoles following repeated exposure to this fungicide class using in vitro bioassays, in vivo studies, and molecular techniques to identify nucleotide missense point mutations associated with the phenotypes (33). All C. cereale isolates identified as thiophanatemethyl resistant had Lys substituted for Glu at amino acid position 198 of the $\beta$ tubulin 2 protein (33).

Based on the frequency of benzimidazole use for anthracnose control in the southeastern United States and the presence of resistance to this fungicide group in $C$. cereale populations, a study was 
initiated to determine whether $C$. cereale isolates causing anthracnose on creeping bentgrass putting greens in Mississippi and Alabama were resistant to the benzimidazole fungicide thiophanate-methyl. The specific objectives included (i) evaluating C. cereale isolates for resistance to thiophanate-methyl using in vitro bioassays and (ii) obtaining nucleotide sequences of the $\beta$-tubulin 2 gene to investigate any missense point mutations resulting in amino acid substitutions.

\section{MATERIALS AND METHODS}

Isolate collection. $C$. cereale was isolated from creeping bentgrass putting greens in Mississippi and Alabama that exhibited symptoms of anthracnose or heat stress during the summer months of 2006 and 2007 (Table 1) (36). Individual plants exhibiting signs (acervuli and setae) of $C$. cereale were surface disinfested by rinsing in $70 \%$ ethanol for $1 \mathrm{~min}$ followed by an agitated rinse in $0.6 \%$ sodium hypochlorite solution for $90 \mathrm{~s}$, rinsed with sterile distilled water three times, and dried on sterile filter paper in a laminar flow hood $(3,20)$. In all, 100 plants (shoots and roots) from each location were transferred ( 5 per plate) onto a modified potato dextrose agar (m-PDA) (6 $\mathrm{g}$ of PDA and $15 \mathrm{~g}$ of agar per liter amended with $100 \mathrm{mg}$ each of chloramphenicol and streptomycin sulfate). The plants were incubated at room temperature (approximately $22^{\circ} \mathrm{C}$ ) on a bench top under 24-h fluorescent light for 4 to 7 days. Fungal colonies producing acervuli, setae, and conidial masses characteristic of $C$. cereale were transferred to fresh m-PDA and incubated as previously described for 21 days. Monoconidial isolates were subsequently obtained through serial dilution. Individual germinating conidia were transferred to m-PDA and incubated as previously described. $C$. $c e$ reale isolates were grown on sterilized glass fiber filter paper (Fisher Scientific, Pittsburg) that was overlaid on PDA (39 g/liter), dried, and subsequently stored at $-20^{\circ} \mathrm{C}$ for long-term storage. Additionally, baseline isolates (never exposed to thiophanate-methyl) were recovered from turftype tall fescue (Lolium arundinaceum (Schreb.) Darbysh) research plots at Mississippi State University and were obtained from Dr. F. Wong, University of California, Riverside $(33,34)$ (Table 1).

In vitro bioassay. Technical-grade thiophanate-methyl (97\% active; Cleary Chemical Corporation, Dayton, NJ) was dissolved in acetone to obtain stock solution at $10,000 \mu \mathrm{g} / \mathrm{ml}$. Serial fourfold dilutions in acetone were used to obtain stock concentrations of thiophanate-methyl at 2,500, 625,156 , and $39 \mu \mathrm{g} / \mathrm{ml}$. In vitro bioassays were performed on m-PDA amended with $1 \mathrm{ml}$ of stock concentrations to obtain final concentrations of thiophanate-methyl at 0 (1 ml of acetone), 0.039, 0.156, 0.625, 2.5, and $10 \mu \mathrm{g} / \mathrm{ml}$. The $10 \mu \mathrm{g} / \mathrm{ml}$ treatment was used as the discriminatory dose at which sensitive or resistant isolates were identified $(27,33)$. A select group of $C$. cereale isolates was also evaluated with thiophanate-methyl-amended medium at $100 \mu \mathrm{g} / \mathrm{ml}$.

All isolates were prepared by removing a 5-mm-diameter hyphal plug from the leading edge of a 10-day-old culture and placing it mycelium-side-down in the center of thiophanate-methyl-amended media. Following a 6-day incubation in the dark, three random measurements of colony diameter $(\mathrm{mm})$ were recorded for each isolate to determine percent relative growth. Percent relative growth was calculated by dividing average radial colony growth on thiophanate-methyl-amended media by average radial colony growth on nonamended media multiplied by 100 .

The effective concentration required to achieve $50 \%$ colony growth inhibition $\left(\mathrm{EC}_{50}\right)$ on thiophanate-methyl-amended media was calculated for isolates evaluated in in vitro bioassays. Percent relative growth for an individual isolate at all thiophanate-methyl-concentrations was subjected to the regression procedure (PROC REG) of SAS (version 9.1; SAS Institute,

Table 1. Colletotrichum cereale isolates collected in 2006 and 2007 from creeping bentgrass golf course putting greens and turf-type tall fescue in Mississippi and Alabama and baseline isolates from California

\begin{tabular}{lllc}
\hline Year & City, state & Population code & No. of isolates \\
\hline 2006 & West Point, MS & OW 15 & 30 \\
2006 & Birmingham, AL & OO 4 & 7 \\
2006 & Birmingham, AL & OO 7 & 9 \\
2006 & Sylacauga, AL & FL & 2 \\
2007 & West Point, MS & OW 15 & 6 \\
2007 & West Point, MS & OW 16 & 7 \\
2007 & Birmingham, AL & OO 7 & 1 \\
2007 & Inverness, AL & GS 4 & 6 \\
2007 & Olive Branch, MS & PGC PG & 2 \\
2007 & Tupelo, MS & BO 6 & 12 \\
2007 & Tupelo, MS & BO 12 & 1 \\
2007 & Starkville, MS & TF & 3 \\
2002 & Temecula, CA & TCGC 5 & 17 \\
\hline
\end{tabular}

${ }^{a}$ Colletotrichum cereale isolates not exposed to thiophanate-methyl were recovered from tall fescue grown at the Rodney R. Foil Research Center at Mississippi State University.

b C. cereale isolates courtesy of Dr. F. Wong, University of California, Riverside $(33,34)$,
Cary, NC) to obtain the intercept $\left(b_{0}\right)$ and slope $\left(b_{1}\right)$. The $\mathrm{EC}_{50}$ value $(\mu \mathrm{g} / \mathrm{ml})$ for each isolate was calculated using the equation thiophanate-methyl $1_{50 \%}=e\left[\left(50-b_{0}\right) / b_{1}\right]$.

The bioassays were conducted each year, repeated, and data were pooled for each isolate.

Sequence analysis of $\beta$-tubulin genes. The $\beta$-tubulin 2 genes from 27 C. cereale isolates, including 23 thiophanate-methylresistant and 4 thiophanate-methyl-sensitive isolates based on bioassay results, were sequenced to identify point mutations leading to amino acid substitutions that confirm thiophanate-methyl resistance. Fresh mycelium was lyophilized for genomic DNA extraction using the protocol described in the DNeasy Plant Mini Kit (Qiagen, Valencia, CA) and stored at $-20^{\circ} \mathrm{C}$.

Polymerase chain reaction (PCR) was used to amplify two subunits of the $\beta$ tubulin gene, $\beta$-tubulin 1 (TUB-1) (556 bp) and $\beta$-tubulin 2 (TUB-2) (500 bp), for each isolate. The primers used for PCR were those described by Wong et al. (33). PCR amplification employed in 2006 included 2 $\mu \mathrm{l}$ of extracted genomic DNA combined with PCR reagent concentrations recommended with the Taq DNA Polymerase with Thermopol Buffer (New England Biolabs, Ipswich, MA), resulting in a final volume of $22 \mu \mathrm{l}$. In 2007, PCR amplification was prepared using the GoTaq PCR Core System (Promega Corp., Madison, WI). All PCR reactions were amplified using the following thermal cycling program: denaturation step at $95^{\circ} \mathrm{C}$ for $5 \mathrm{~min}$; followed by 30 cycles of $94^{\circ} \mathrm{C}$ for $1 \mathrm{~min}$, $57^{\circ} \mathrm{C}$ for $1 \mathrm{~min}$, and $72^{\circ} \mathrm{C}$ for $1 \mathrm{~min}$; followed by a final extension at $72^{\circ} \mathrm{C}$ for 10 min. The amplicon was visualized by performing electrophoresis in a $1.5 \%$ agarose gel to ensure a single product. Excess primer or dNTPs in solution were removed using ExoSAP-IT (USB Corporation, Cleveland) according to the manufacturer's instructions.

PCR amplicons were sequenced at the University of California, Riverside Genomics Core Sequencing facility using Big Dye Terminator v3.1 chemistry (Applied Biosystems, Foster City, CA) in 2006. In 2007, PCR amplicons were prepared for sequencing using the DTCS Quick Start Kit (Beckman and Coulter, Fullerton, CA) and sequenced at the Life Sciences and Biotechnology Institute at Mississippi State University using the Beckman CEQ 8000 DNA Analysis System (Beckman and Coulter). Resultant nucleotide sequences were translated, aligned, and analyzed using DNASTAR Lasergene Software (DNASTAR Inc., Madison, WI). All isolates were sequenced twice.

\section{RESULTS}

In vitro bioassay. Radial colony growth of all $83 C$. cereale isolates collected from fungicide-treated creeping bentgrass putting greens in Mississippi and Alabama 
was classified as resistant to thiophanatemethyl at the discriminatory dose of 10 $\mu \mathrm{g} / \mathrm{ml}$. Relative growth of these isolates ranged from 77.5 to $130.7 \%$ with a mean of $99.3 \%$. In contrast, relative growth of sensitive isolates ranged from 0.0 to $48.7 \%$ with a mean of $20.4 \%$ with thiophanatemethyl at $10 \mu \mathrm{g} / \mathrm{ml}$.

Relative growth of resistant isolates was similar across all concentrations, whereas sensitive isolates exhibited reduced colony growth with thiophanate-methyl at 0.625 $\mu \mathrm{g} / \mathrm{ml}$ and higher (Fig. 1A and B). The $\mathrm{EC}_{50}$ values for thiophanate-methylresistant $C$. cereale isolates were considered to be greater than $10 \mu \mathrm{g} / \mathrm{ml}$ due to minimal inhibition at this concentration. Similarly, selected isolates exhibited minimal colony inhibition with thiophanate-methyl at $100 \mu \mathrm{g} / \mathrm{ml}$. However, the $\mathrm{EC}_{50}$ of the sensitive isolates for thiophanate-methyl ranged from 0.6 to $8.2 \mu \mathrm{g} / \mathrm{ml}$ with a mean of $3.0 \mu \mathrm{g} / \mathrm{ml}$.

Sequence analysis of $\beta$-tubulin genes. Nucleotide sequences of the Tub- 1 gene of nine $C$. cereale isolates were obtained in 2006 corresponding to a representative sample from each creeping bentgrass putting green sampled. The TUB-1 sequence corresponded to amino acid positions 180 to 329 (25). No differences between deduced amino acid sequences were observed among these isolates. C. cereale isolates sensitive or resistant to thiophanate-methyl from Mississippi and Alabama resulted in nucleotide sequences that were similar, ranging from 94.0 to $99.8 \%$ identity. The consensus nucleotide sequence of $T U B-1$ from these isolates was $98 \%$ identical to the $T U B-1$ sequences obtained from C. cereale isolates from California (33) and $92 \%$ identical to the original nucleotide sequence for $C$. graminicola's TUB-1 (accession no. M34491). The locations where nucleotide sequences differed between resistant and sensitive $C$. cereale isolates ultimately coded for the same amino acid (data not shown). TUB-1 was not sequenced for isolates in 2007 due to the similarity of sequences and lack of consistent missense point mutations in resistant isolates compared with sensitive isolates in 2006.

Nucleotide sequences from 27 isolates (23 thiophanate-methyl-resistant and 4 thiophanate-methyl-sensitive) were obtained from purified PCR product of the $T U B-2$ gene. The amplified $T U B-2$ nucleotide sequence corresponded to amino acid positions 163 to 303 (25), containing the residues at positions 198 and 200 typically associated with benzimidazole resistance. Based on the translation of nucleotide sequences obtained, $52 \%$ of the isolates classified as resistant had an amino acid change from Glu to Ala at position 198 (E198A) (Fig. 2). The remaining resistant isolates had an amino acid change from Phe to Tyr at position 200 (F200Y) (Fig. 2). The four sensitive isolates, including those from tall fescue, retained Glu and Phe at positions 198 and 200, respectively, similar to the original C. graminicola TUB2 sequence (accession no. M34492) (Fig. 2). There were no other deduced changes in amino acid sequence in the resistant isolates that were consistent with the observed isolate phenotypes or were typical of those conferring resistance to the benzimidazole fungicides. Nucleotide sequences obtained from isolates were identical when the sequencing was repeated.

Benzimidazole-resistant fungi with substitutions at amino acid positions 198 or 200 have been characterized as intermediately or highly resistant based on $\mathrm{EC}_{50}$ values (7,21,35); however, selected $C$. cereale isolates with E198A and F200Y substitutions evaluated in this study were not inhibited with thiophanate-methyl at $100 \mu \mathrm{g} / \mathrm{ml}$, expressing highly resistant responses. Relative growth of isolates with the E198A exchange ranged from 90.0 to $104.7 \%$ with a mean of $98.0 \%$ for thiophanate-methyl at $100 \mu \mathrm{g} / \mathrm{ml}$, whereas those with the F200Y substitution ranged from 90.9 to $103.4 \%$ with a mean of $95.3 \%$ at $100 \mu \mathrm{g} / \mathrm{ml}$. Based on these results, $\mathrm{EC}_{50}$ values of both groups of isolates were considered to be greater than $100 \mu \mathrm{g} / \mathrm{ml}$.

\section{DISCUSSION}

Thiophanate-methyl-resistant isolates of C. cereale originating from creeping bentgrass putting greens in Mississippi and Alabama were identified. C. cereale isolates were collected from golf course putting greens where thiophanate-methyl was applied on a regular basis for several years to control turfgrass diseases. Based on the history of thiophanate-methyl use at the golf courses, these results were not unexpected, considering similar reports of $C$.

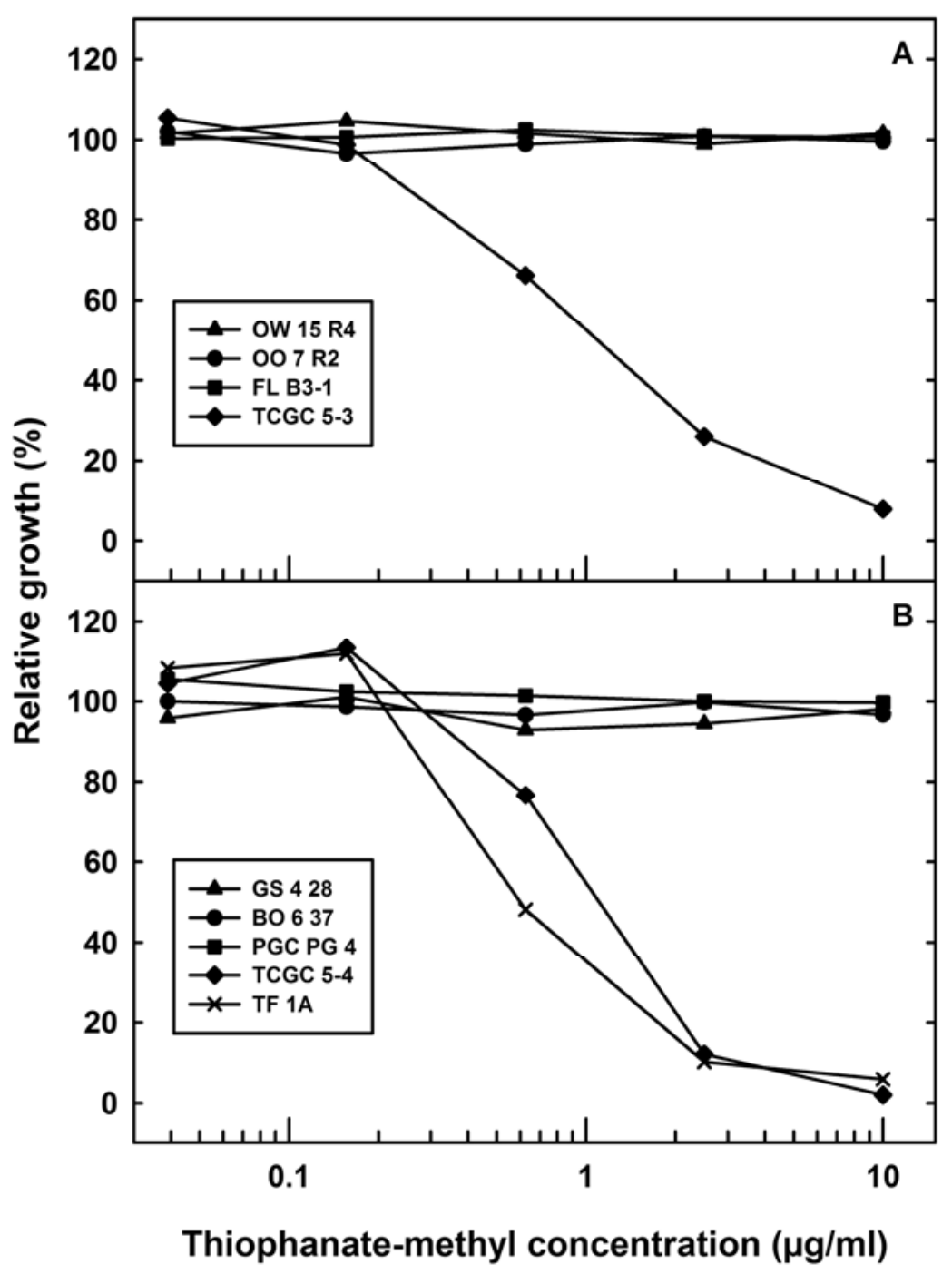

Fig. 1. Representative sample of the relative growth from thiophanate-methyl-sensitive and -resistant Colletotrichum cereale isolates cultured on thiophanate-methyl-amended media at $0.039,0.156,0.625$, 2.5 , and $10 \mu \mathrm{g} / \mathrm{ml}$. Radial growth was recorded after incubating at room temperature (approximately $22^{\circ} \mathrm{C}$ ) in the dark for 6 days. Relative growth was calculated by dividing average radial colony growth on thiophanate-methyl-amended media by average radial colony growth on nonamended media and multiplied by 100 . Data points are plotted at the concentrations evaluated with the $\mathrm{x}$-axis on a $\log$ scale. A, Dose response curve, 2006 isolates. B, Dose response curve, 2007 isolates. 
cereale resistance occurring at other locations in the United States $(6,19,24,30,31)$. However, this is the first identification of thiophanate-methyl resistance in $C$. cereale isolated from creeping bentgrass putting greens.
The phenotypic response of thiophanatemethyl resistance in $C$. cereale isolates in this study was supported at the molecular level based on methods previously reported on benzimidazole-resistant $C$. $\mathrm{Ce}$ reale isolated from annual bluegrass in
California (33). In this study, two separate amino acid substitutions, E198A and F200Y, were observed in the $\beta$-tubulin 2 protein of $C$. cereale isolates that were not inhibited at the discriminatory dose of thiophanate-methyl at $10 \mu \mathrm{g} / \mathrm{ml}$. This is the

\begin{tabular}{|c|c|c|c|c|c|}
\hline Isolate ID & $\begin{array}{l}\text { GenBank } \\
\text { Accession \# }\end{array}$ & & 170 & 180 & 200 \\
\hline BO 69 (res) & FJ476048 & ATFSV & VPSPKVSDTV & VEPYNATLSV & HQLVENSDAT FCIDNE \\
\hline BO 637 (res) & $J 476049$ & TFSV & VPSPKVSDTV & VEPYNATLSV & HQLVENSD \\
\hline BO 123 (res) & FJ476050 & ATFSV & VPSPKVSDTV & VEPYNATLSV & HQLVENSDAT FCIDNE \\
\hline L A2-1 (res) & FJ476051 & ATFSV & VPSPKVSDTV & VEPYNATLSV & HQLVENSD \\
\hline L B3-1 (res) & FJ476052 & ATFSV & VPSPKVSDTV & VEPYNATLSV & HQLVENSD \\
\hline GS 422 (res) & FJ476053 & ATFSV & VPSPKVSDTV & VEPYNATLSV & HQLVENSDE \\
\hline GS 428 (res) & FJ476054 & ATFSV & VPSPKVSDTV & VEPYNATLSV & HQLVENSDET YCIDNE \\
\hline OO 4 G1-1 (res) & FJ476055 & ATFSV & VPSPKVSDTV & VEPYNATLSV & HQLVENSDAT FCIDNE \\
\hline OO 4 K1-1 (res) & FJ476056 & ATFSV & VPSPKVSDTV & VEPYNATLSV & HQLVENSDAT FCIDNE \\
\hline OO 4 O1-2 (res) & FJ476057 & ATFSV & VPSPKVSDTV & VEPYNATLSV & HQLVENSDAT FCIDNE \\
\hline 071 (res) & FJ476058 & ATFSV & VPSPKVSDTV & VEPYNATLSV & HQLVENSDET YCIDNE \\
\hline DO 7 E5-1 (res) & FJ476059 & ATFSV & VPSPKVSDTV & VEPYNATLSV & HQLVENSDAT FCIDNE \\
\hline OO 7 R1-1 (res) & FJ476060 & ATFSV & VPSPKVSDTV & VEPYNATLSV & HQLVENSDAT FCIDNE \\
\hline OO 7 R2-1 (res) & FJ476061 & ATFSV & VPSPKVSDTV & VEPYNATLSV & HQLVENSDAT FCIDNE \\
\hline OW 15 52B (res) & FJ476062 & TFSV & VPSPKVSDTV & VEPYNATLSV & HQLVENSDET YCIDNE \\
\hline DW 15 56B (res) & FJ476063 & TFSV & VPSPKVSDTV & VEPYNATLSV & HQLVENSDAT FCIDNE \\
\hline DW 15 I4b-1 (res) & FJ476064 & TFSV & VPSPKVSDTV & VEPYNATLSV & HQLVENSDAT FCIDNE \\
\hline OW 15 N5b (res) & FJ476065 & ATFSV & VPSPKVSDTV & VEPYNATLSV & HQLVENSDAT FCIDNE \\
\hline OW 15 R4-1 (res) & FJ476066 & ATFSV & VPSPKVSDTV & VEPYNATLSV & HQLVENSDAT FCIDNE \\
\hline OW $161 \mathrm{C}$ (res) & FJ476067 & TFSV & VPSPKVSDTV & VEPYNATLSV & HQLVENSDET YCIDNE \\
\hline OW 16 14B (res) & FJ476068 & ATFSV & VPSPKVSDTV & VEPYNATLSV & HQLVENSDET YCIDNE \\
\hline PGC PG 1 (res) & FJ476069 & ATFSV & VPSPKVSDTV & VEPYNATLSV & HQLVENSDET YCIDNE \\
\hline PGC PG 4 (res) & FJ476070 & ATFSV & VPSPKVSDTV & VEPYNATLSV & HQLVENSL \\
\hline TCGC 5-35 (sens) & EU116291 & ATFSV & VPSPKVSDTV & VEPYNATLSV & HQLVENSDET FCIDNE \\
\hline TCGC 5-48 (sens) & GQ121136 & ATFSV & VPSPKVSDTV & VEPYNATLSV & HQLVENSDET FCIDNE \\
\hline TF $1 \mathrm{~A}$ (sens) & FJ476071 & ATFSV & VPSPKVSDTV & VEPYNATLSV & HQLVENSDET FCIDNE \\
\hline TF $1 C$ (sens) & FJ476072 & ATFSV & VPSPKVSDTV & VEPYNATLSV & HQLVENSDET FCIDNE \\
\hline IUB-2 (Gen & M34492 & FSV & PSPKVSDTV & VEPYNATLSV & I HQLVENSL \\
\hline
\end{tabular}

Fig. 2. Amino acid sequences spanning residues 165 to 206 of the $\beta$-tubulin 2 protein for 27 Colletotrichum cereale isolates identified as resistant (res) or sensitive (sens) to thiophanate-methyl based on in vitro data. These sequences were compared with the original $\beta$-tubulin 2 protein in GenBank. The key amino acids are located at positions 198 and 200, and changes are highlighted. 
first report of the E198A substitution identified in $C$. cereale and is in contrast to thiophanate-methyl-resistant $C$. cereale isolates from annual bluegrass identified with the amino acid substitution E198K (33). The E198A substitution has been previously reported, however, in thiophanatemethyl-resistant C. gloeosporioides (Penz.) Penz. \& Sacc., a pathogen infecting various crops $(7,23,26)$.

The F200Y substitution was also observed in some of the thiophanate-methylresistant isolates collected in this study. To date, no amino acid substitution at position 200 in the $\beta$-tubulin 2 gene of $C$. cereale has been reported; however, two isolates of C. gloeosporioides exhibiting the F200Y exchange were previously reported (7). Benzimidazole-resistant fungi exhibiting amino acid substitutions at position 200 or 198 have been characterized as intermediately or highly resistant, respectively, based on $\mathrm{EC}_{50}$ values $(7,21,35)$. Various fungal isolates with an amino acid substitution at position 198 were considered highly resistant $\left(\mathrm{EC}_{50}>100 \mu \mathrm{g} / \mathrm{ml}\right)$, whereas isolates with an amino acid substitution at position 200 were considered to have intermediate resistance $(7,21,35)$. $C$. cereale isolates expressing E198A or F200Y substitutions in this study had similar colony growth with thiophanate-methyl at 10 or $100 \mu \mathrm{g} / \mathrm{ml}$. $\mathrm{EC}_{50}$ values among these isolates were $>100 \mu \mathrm{g} / \mathrm{ml}$, which were in contrast to previous reports $(7,21,35)$. The results in this study indicate that the phenotypic display of colony growth among the Mississippi and Alabama isolates differed from those of other pathogens.

Key differences in amino acid substitutions were observed among $C$. cereale isolates collected from creeping bentgrass putting greens in Mississippi and Alabama compared with previous reports for $C$. cereale infecting annual bluegrass putting greens (33). These differences may be due, in part, to the host or regional location of these isolates. Phylogenetic analysis data were generated by Crouch et al. (11) to separate an extensive group of Colletotrichum spp. isolated from numerous warm- and cool-season gramineous species. The study demonstrated the separation of Colletotrichum spp., of which three clades primarily contained $C$. cereale isolates from creeping bentgrass or annual bluegrass, making it apparent that the isolates were distinguishable based on host specificity. Geographic regions did not influence the relatedness of $C$. cereale isolates (11). This information led us to hypothesize that the amino acid substitutions observed in $C$. cereale isolates from creeping bentgrass versus amino acid substitutions observed in $C$. cereale isolates from annual bluegrass may be a result of host specificity.

The differences in relative growth based on in vitro bioassays were evident when comparing sensitive and resistant $C$. $c e$ reale isolates at high concentrations of thiophanate-methyl. Sensitive isolates exhibited reduced colony growth at concentrations of thiophanate-methyl $\geq 0.625$ $\mu \mathrm{g} / \mathrm{ml}$. Colony growth inhibition was not observed among isolates considered resistant to thiophanate-methyl at concentrations $\geq 10 \mu \mathrm{g} / \mathrm{ml}$. Although the isolates in this study were not tested in planta, they appear to behave similarly to those reported as resistant by Wong et al. (33). The relative growth of these isolates at the discriminatory dose of $10 \mu \mathrm{g} / \mathrm{ml}$ corresponded to those classified by Wong et al. (33) as resistant. Relative growth values for thiophanate-methyl-sensitive isolates were also consistent with those characterized by Wong et al. (33). The dose response curves (Fig. 1) of selected isolates further illustrate the behavior of all $C$. cereale isolates considered resistant in this study.

Results from this research may not be inclusive of all $C$. cereale isolates within existing populations due to a limited sampling size but thiophanate-methyl-resistant isolates must have been present at high frequencies in the populations sampled. Previously, no data were reported for $C$. cereale isolated from creeping bentgrass putting greens regarding thiophanatemethyl resistance. However, this study identified similar results from in vitro bioassays when compared with what was reported for the pathogen from annual bluegrass $(9,13,33)$. Based on the current research, thorough sampling within these C. cereale populations may provide a more accurate measure of the magnitude of resistant versus sensitive isolate occurrence in creeping bentgrass putting greens. The fact that thiophanate-methyl-resistant $C$. cereale isolates are present in creeping bentgrass putting greens in Mississippi and Alabama should raise awareness among golf course superintendents that fungicide resistance management needs to be considered in management programs. Disease management strategies consisting of nitrogen fertility, growth regulators, and vertical mowing that reduced anthracnose on annual bluegrass (15) should be investigated to determine the efficacy of anthracnose control on creeping bentgrass in Mississippi and Alabama.

Based on the documentation of thiophanate-methyl-resistant isolates of $C$. cereale present in creeping bentgrass golf course putting greens in Mississippi and Alabama, fungicide resistance appears to be more pervasive within $C$. cereale populations than previously thought. No sensitive isolates were identified from golf course putting greens with a history of thiophanate-methyl applications. Based on previous reports of a high frequency of fungicide resistance within $C$. cereale populations (33), it is apparent that this trend will continue in highly managed creeping bentgrass putting greens. Based on the results of this study, it is recommended that proactive disease management strategies be implemented for thiophanate-methyl resistance and resistance to other single-site mode-of-action fungicides.

\section{ACKNOWLEDGMENTS}

Funding was provided by the Mississippi Agricultural and Forestry Experimental Station and approved for publication, J-11510. We thank the golf course superintendents for access to collect creeping bentgrass samples at their respective golf courses and student workers at Mississippi State University and the University of California, Riverside turfgrass pathology labs for their assistance in the research project.

\section{LITERATURE CITED}

1. Anonymous. Fungicide Resistance Action Committee. 2009. FRAC code list 2009. Available online at: http://www.frac.info/frac/index. htm. Crop Life, Brussels.

2. Avila-Adame, C., Olaya, G., and Köller, W. 2003. Characterization of Colletotrichum graminicola isolates resistant to strobilurinrelated QoI fungicides. Plant Dis. 87:14261431.

3. Backman, P. A., Landschoot, P. J., and Huff, D. R. 1999. Variation in pathogenicity, morphology, and RAPD marker profiles in Colletotrichum graminicola from turfgrasses. Crop Sci. 39:1129-1335.

4. Bishop, P., Sorochan, J., Ownley, B. H., Samples, T. J., Windham, A. S., Windham, M. T., and Trigiano, R. N., 2008. Resistance of Sclerotinia homoeocarpa to iprodione, propiconazole, and thiophanate methyl in Tennessee and northern Mississippi. Crop Sci. 48:1615-1620.

5. Buhr, T. L., and Dickman, M. B. 1994. Isolation, characterization, and expression of a second $\beta$-tubulin-encoding gene from Colletotrichum gloeosporioides f. sp. Aeschynomene. Appl. Environ. Microbiol. 60:4155-4159.

6. Burpee, L. L., Stephens, S. L., and MartinezEspinoza, A. D. 2004. Control of anthracnose caused by a benzimidazole- and QoI-resistant isolate of Colletotrichum graminicola, 2003. Fungic. Nematicide Tests 59:T016.

7. Chung, W., Ishii, H., Nishimura, K., Fukaya, M., Yano, K., and Kajitani, Y. 2006. Fungicide sensitivity and phylogenetic relationship of anthracnose fungi isolated from various fruit crops in Japan. Plant Dis. 90:506-512.

8. Clark, B. B., and Murphy, J. A. 2004. Management practices associated with anthracnose and abiotic stress on golf course turf. Rutgers Cooperative Extension, New Brunswick, NJ. Available online at: http://www.paton.com.au/ Research/Turf/Disease/managementpractices associatedwithanthracnose.pdf.

9. Crouch, J. A., Clarke, B. B., and Hillman, B. I. 2005. Phylogenetic relationships and fungicide sensitivities of Colletotrichum graminicola isolates from turfgrass in North America. Int. Turfgrass Soc. Res. 10:186-195.

10. Crouch, J. A., Clarke, B. B., and Hillman, B. I 2006. Unraveling evolutionary relationships among the divergent lineages of Colletotrichum causing anthracnose disease in turfgrass and corn. Phytopathology 96:46-60.

11. Crouch, J. A., Tredway, L. P., Clarke, B. B., and Hillman, B. I. 2009. Phylogenetic and population genetic divergence correspond with habitat for the pathogen Colletotrichum cereale and allied taxa across diverse grass communities. Mol. Ecol. 18:123-135.

12. Davidson, R. M., Hanson, L. E., and Panella, L. 2006. Analysis of $\beta$-tubulin gene fragments from benzimidazole-sensitive and -tolerant Cercospora beticola. J. Phytopa- 
thol. 154:321-328.

13. Detweiler, A. R., Vargas, J. M., Jr., and Berndt, W. L. 1989. Resistance of Colletotrichum graminicola to benomyl. Proc. Int. Turf. Res. Conf. 6:359-362.

14. Gafur, A., Tanaka, C., Shimizu, K., Ouchi, S., and Tsuda, M. 1998. Molecular analysis and characterization of the Cochliobolus heterostrophus $\beta$-tubulin gene and its possible role in conferring resistance to benomyl. J. Gen. Appl. Microbiol. 44:217-223.

15. Inguagiato, J. C., Murphy, J. A., and Clarke, B. B. 2008. Anthracnose severity on annual bluegrass influenced by nitrogen fertilization, growth regulators, and verticutting. Crop Sci. 48:1595-1607.

16. Jo, Y. K., Niver, A. L., Rimelspach, J. W., and Boehm, M. J. 2006. Fungicide sensitivity of Sclerotinia homoeocarpa from golf courses in Ohio. Plant Dis. 90:807-813.

17. Jung, M. K., and Oakley, B. R. 1990. Identification of an amino acid substitution in the benA, $\beta$-tubulin gene of Aspergillus nidulans that confers thiabendazole resistance and benomyl supersensitivity. Cell Motil. Cytoskelet. 17:87-94.

18. Jung, M. K., Wilder, I. B., and Oakley, B. R. 1992. Amino acid alterations in the benA ( $\beta$ tubulin) gene of Aspergillus nidulans that confer benomyl resistance. Cell Motil. Cytoskelet. 22:170-174.

19. Kaminski, J. E., and Kennelly, M. G. 2007. Preventive control of anthracnose basal rot on an annual bluegrass putting green, 2006. Plant Dis. Manage. Rep. 1:T012.

20. Khan, A., and Hsiang, T. 2003. The infection process of Colletotrichum graminicola and relative aggressiveness on four turfgrass species. Can. J. Microbiol. 49:433-442.

21. Koenraadt, H., Somerville, S. C., and Jones, A. L. 1992. Characterization of mutations in the beta-tubulin gene of benomyl-resistant field strains of Venturia inaequalis and other plant pathogenic fungi. Phytopathology 82:13481354.

22. Ma, Z., Yoshimura, M. A., and Michailides, T. J. 2003. Identification and characterization of benzimidazole resistance in Monilinia fructicola from stone fruit orchards in California. Appl. Environ. Microbiol. 69:7145-7152.

23. Maymon, M., Zveibil, A., Pivonia, S., Minz, D., and Freeman, S. 2006. Identification and characterization of benomyl-resistant and -sensitive populations of Colletotrichum gloeosporioides from statice (Limonium spp.). Phytopathology 96:542-548.

24. McCullough, M. D., and Wong, F. P. 2005. Evaluation of mid-season fungicide applications for the control of anthracnose on a mixed annual bluegrass and creeping bentgrass green in northern California, summer 2004. Fungic. Nematicide Tests 60:T056.

25. Panaccione, D. G., and Hanau, R. M. 1989. Characterization of two divergent $\beta$-tubulin genes from Colletotrichum graminicola. Gene 86:163-170.

26. Peres, N. A., Souza, N. L., Peever, T. L., and Timmer, L. W. 2004. Benomyl sensitivity of isolates of Colletotrichum acutatum and $C$. gloeosporioides from citrus. Plant Dis. 88:125130.

27. Russel, P. E. 2004. Sensitivity Baselines in Fungicide Resistance Research and Management. FRAC Monograph No. 3. Crop Life, Brussels.

28. Schmidt, L. S., Ghosoph, J. M., Margosan, D. A., and Smilanick, J. L. 2006. Mutation at $\beta$ tubulin codon 200 indicated thiabendazole resistance in Penicillium digitatum collected from California citrus packinghouses. Plant Dis. 90:765-770.

29. Smiley, R. W., Dernoeden, P. H., and Clarke, B. B. 2005. Compendium of Turfgrass Diseases, 3rd ed. American Phytopathological So- ciety Press, St. Paul, MN.

30. Towers, G., Green, K., Weibel, E., Majumdar, P., and Clarke, B. B. 2003. Evaluation of fungicides for control of anthracnose basal rot on annual bluegrass, 2002. Fungic. Nematicide Tests 58:T017.

31. Uddin, W., Soika, M. D., Shelton, J., and Soika, E. L. 2001. Evaluation of fungicides for the control of anthracnose on annual bluegras and creeping bentgrass, 2000. Fungic. Nematicide Tests 56:T17

32. Vincelli, P., and Dixon, E. 2002. Resistance to QoI (strobilurin-like) fungicides in isolates of Pyricularia grisea from perennial ryegrass. Plant Dis. 86:235-240.

33. Wong, F. P., de la Cerda, K. A., HernandezMartinez, R., and Midland, S. L. 2008. Detection and characterization of benzimidazole resistance in California populations of Colletotrichum cereale. Plant Dis. 92:239-246.

34. Wong, F. P., Midland, S. L., and de la Cerda, K. A. 2007. Occurrence and distribution of QoI-resistant isolates of Colletotrichum cereale from annual bluegrass in California. Plant Dis. 91:1536-1546.

35. Yarden, O., and Katan, T. 1993. Mutations leading to substitutions at amino acids 198 and 200 of beta-tubulin that correlate with benomyl-resistance phenotypes of field strains of Botrytis cinerea. Phytopathology 83:14781483.

36. Young, J. R. 2009. Identification of strobilurin and benzimidazole resistance in Colletotrichum cereale isolates causing anthracnose on creeping bentgrass putting greens in Mississippi and Alabama. M.Sc. thesis, Mississippi State University, Mississippi State.

37. Young, J. R., Tomaso-Peterson, M., and Crouch, J. A. 2008. First report of Colletotrichum cereale causing anthracnose foliar blight of creeping bentgrass in Mississippi and Alabama. Plant Dis. 92:1475. 